
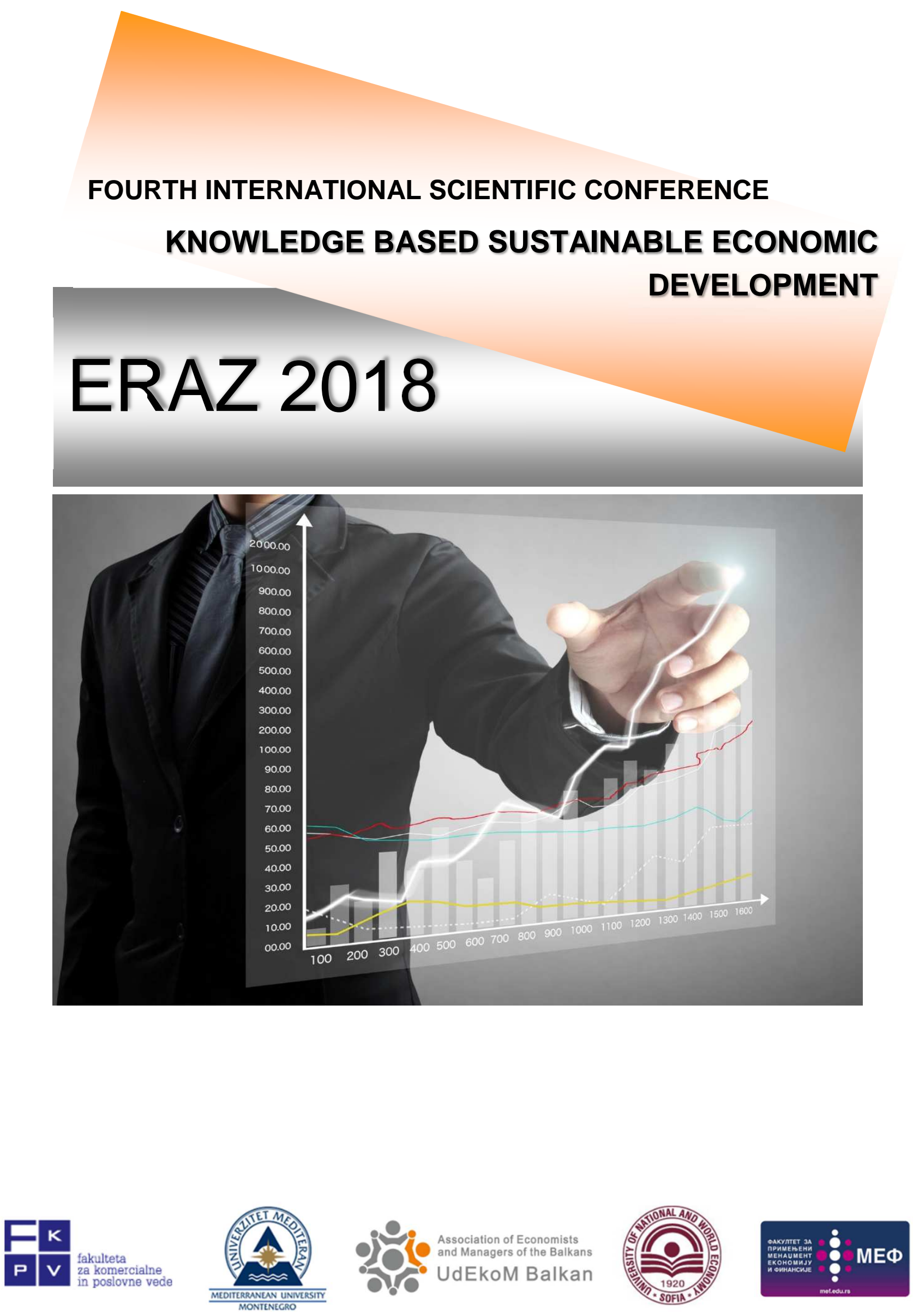

FOURTH INTERNATIONAL SCIENTIFIC CONFERENCE ERAZ 2018

KNOWLEDGE BASED SUSTAINABLE ECONOMIC DEVELOPMENT

\section{CONFERENCE PROCEEDINGS}




\section{Conference ERAZ 2018}

Conference Proceedings - KNOWLEDGE BASED SUSTAINABLE ECONOMIC DEVELOPMENT

\section{Scientific Committee}

1. Christian Tanushev, PhD, Associate Professor, Vice Dean for International Cooperation, Faculty of Management and Administration, University of National and World Economy, Sofia, Bulgaria

2. Dragoljub Janković, PhD, Associate Professor, Dean, Faculty of Business Studies, Mediterranean University, Podgorica, Montenegro

3. Evgenia Yazovskikh, PhD, Associate Professor, Marketing Department, Ural federal University named after the first President of Russia B.N. Yeltsin, Yekaterinburg, Russia

4. Tatjana Kovač, $\mathrm{PhD}$, Assistant Professor, Vice Dean, Faculty of Business and Commercial Sciences, Celje, Slovenia

5. Vesna Milanović, PhD, Full Time Professor, Faculty of International Economics, University John Naisbitt, Belgrade, Serbia

6. Jelena Žugić, PhD, Associate Professor, Vice Dean for Academic Affairs, Finance and International Cooperation, Faculty of Business Studies, Mediterranean University, Podgorica, Montenegro

7. Ivana Simić, PhD, Full Time Professor, Faculty of Economics, University of Niš, Niš, Serbia

8. Galina Mladenova, PhD, Associate Professor, Vice Dean, Faculty of Management and Administration, University of National and World Economy, Sofia, Bulgaria

9. Dragana Bašić, $\mathrm{PhD}$, Associate Professor, Head of the Department of Accounting and Business Finance, Faculty of Economics, University of Banja Luka, Bosnia and Herzegovina

10. Elvis Mujačević, PhD, Full Time Professor, Faculty of Tourism and Hospitality Management Opatija, University of Rijeka, Republic of Croatia

11. Tatjana Dolinšek, PhD, Assistant Professor, Faculty of Commercial and Business Sciences, Celje, Slovenia

12. Gabriela Lobonțiu, PhD, Associate Professor, Faculty of Engineering, Department of Engineering and Technology Management, Technical University of Cluj-Napoca, North University of Baia Mare Centre, Maramures, Romania

\section{Organizational Committee:}

Vuk Bevanda, PhD, Associate Professor; Nikolina Vrcelj, PhD candidate Nevena Vrcelj, PhD student; Pavle Brzaković, PhD student, Danijela Rutović, BSc; Ivana Mirčević, BSc; Uroš Mirčević, Ing.; Goran Stevanović, BSc; Ana Rusić, BSc

\section{Published by:}

Association of Economists and Managers of the Balkans - Belgrade, Serbia; Faculty of Business Studies, Mediterranean University - Podgorica, Montenegro; University of National and World Economy - Sofia, Bulgaria; Faculty of Commercial and Business Studies - Celje, Slovenia; Faculty of Applied Management, Economics and Finance - Belgrade, Serbia

Printed by: All in One Print Center, Belgrade

Belgrade, 2018

\section{ISBN 978-86-80194-12-7}

DOI: https://doi.org/10.31410/eraz.2018
13. Edmond Hoxha, PhD, Full Time Professor, Department of Mineral Resources, Faculty of Geology and Mine, Polytechnic University of Tirana, Tirana, Albania

14. Slobodanka Krivokapić, PhD, Associate Professor, Faculty of Business Studies, Mediterranean University, Podgorica, Montenegro

15. Nadežda Fuksová, PhD, Assistant Professor, Slovak University of Technology, Institute of Management, Bratislava, Slovak Republic

16. Yovka Bankova, PhD, Assistant Professor, Department of Marketing and Strategic Planning, University of National and World Economy, Sofia, Bulgaria

17. Stefan O. Grbenic, PhD, Assistant Professor, Institute of Business Economics and Industrial Sociology, University of Technology, Graz, Austria

18. Denis Tomše, PhD, Assistant Professor, Faculty of Commercial and Business Sciences, Celje, Slovenia

19. Tomislav Brzaković, PhD, Associate Professor, Dean, Faculty of Applied Management, Economy and Finance, Belgrade, Serbia

20. Miodrag Brzaković, PhD, Associate Professor, Faculty of Applied Management, Economy and Finance, Belgrade, Serbia

21. Saša Virijević Jovanović, PhD, Associate Professor, Faculty of Applied Management, Economy and Finance, Belgrade, Serbia

22. Fadil Zendeli, PhD, Associate Professor, South East European University, Faculty of Public Administration and Political Sciences, Tetovo, Republic of Macedonia

23. Milica Nestorović, PhD, Assistant Professor, Faculty of Business Studies, University John Naisbitt, Belgrade, Republic of Serbia

24. Đurđica Vukajlović, PhD, Assistant Professor, Faculty of Applied Management, Economy and Finance, Belgrade, Serbia

CIP - Каталогизација у публикацији -

Народна библиотека Србије, Београд

$338.1(082)$

$330.3(082)$

$336(082)$

$005(082)$

007:004(082)

INTERNATIONAL Scientific Conference Knowledge Based Sustainable Economic Development ERAZ 2018 (2018; Sofija) (4)

Conference Proceedings / Fourth International Scientific Conference

Knowledge Based Sustainable Economic Development ERAZ 2018, Sofia, Bulgaria

June 7, 2018. - Belgrade [etc.] : Association of Economists and Managers of the Balkans [etc.], 2018 (Beograd : All in one print center). - XXVII, 910

str. : graf. prikazi, tabele ; $29 \mathrm{~cm}$

Tiraž 100. - Napomene i bibliografske reference uz tekst. Registar. -

Bibliografija uz svaki rad. - Abstracts.

ISBN 978-86-80194-12-7 (AEMB)

a) Економија - Зборници b) Привредни развој -

Зборници с) Финансије -

Зборници d) Менашмент - Зборници е) Информациона технологија - Зборници

COBISS.SR-ID 269456652 
AFRICAN UNION AND EUROPEAN SUSTAINABLE DEVELOPMENT PROJECTS: CROSS-CULTURAL TRAPS IN MULTICULTURAL TEAMS ....................................... 2 Mary Ellen Toffle

PROBLEMS IN THE BUSINESS OF SMALL AND MEDIUM-SIZED ENTERPRISES AND ENTREPRENEURSHIP IN SERBIA 16

Marina Gajic Glamoclija

INEQUALITY PROBLEMS IN CENTRAL AND EASTERN EUROPE 22

Gyorgy Andor

FOREIGN DIRECT INVESTMENT AND REGIONAL DEVELOPMENT IN BULGARIA: A PANEL DATA ANALYSIS FOR THE PERIOD 2008-2016

Iva Raycheva

FOREIGN DIRECT INVESTMENT IN MACEDONIA - IS THERE

DICRIMINATION IN PRACTICE?

Biljana Petrevska

MITIGATION OF REGIONAL DISPARITIES THROUGH CLUSTERS 47

Katarína Král'ová

Jana Sochul'áková

Dagmar Petrušová

INFLUENCE OF FOREIGN TRADE WITH CEFTA AND EU ON GDP OF B\&H.....55

Dijana Grahovac

Senad Softić

CROSS-BORDER REGIONS AS SUPPORTING STRUCTURES FOR RAISING COMPETITIVENESS IN EUROPE 65

Dagmar Škodová Parmová

Zuzana Dvořáková Líšková

Rostislav Kain

THE INFLUENCE OF MUNICIPALITY SIZE ON ITS EXPENDITURE- CASE STUDY FROM SLOVAKIA

Monika Vámošová

DYNAMICS OF LOANS AND DEPOSITS IN BULGARIA AND THE EURO AREA IN THE PERIOD 2007-2017 86

Aglika Kaneva

CHALLENGE FOR A NON-FINANCIAL DEFINED CONTRIBUTION SCHEME IN THE ALBANIAN RETIREMENT SYSTEM 
Landi Gushi

INCOME RELATED ELASTICITY OF HEALTH EXPENDITURE: SOME

EMPIRICAL EVIDENCE FOR BULGARIA 106

Nikolay Atanasov

RETIREMENT PROGRAMS FOR EMPLOYEES AS AN ELEMENT OF

CORPORATE SOCIAL RESPONSIBILITY

Iwona Olejnik

Magdalena Stefańska

MICROFINANCE AND ECONOMIC GROWTH IN ALBANIA: AN ARDL

APPROACH

Forcim Kola

Teuta Cerpja

FINDING THE EFFECTIVE FRONTIER FOR A PORTFOLIO OF RISK LOANS

(ALBANIAN CASE)

Glediana Zeneli

Arsen Benga

BANKS IN THE SYSTEM OF FINANCING ECONOMY AND FINANCIAL

MANAGEMENT IN BOSNIA AND HERZEGOVINA

Željana Vrućinić

THE PROFITABILITY OF BANKING SECTOR IN KOSOVO

Flamur Keqa

MOTIVES AND DETERMINANTS OF THE PROCESSES OF MERGERS AND ACQUISITIONS OF BANKS IN THE USA, EU, AND TRANSITIONAL ECONOMIES OF CENTRAL AND EASTERN EUROPE

Irena Lekoska

ECB LEGAL MEASURES ACCORDING TO THE FINANCIAL CRISES 176

Shkendije Nahi

Flamur Mrasori

DEVELOPING E-BANKING PLATFORM IN CONTEMPORARY WORLD. 185

Zarko Radjenovic

Tatjana Boshkov

WILL THE INTERNATIONAL ACCOUNTING STANDARDS BOARD'S DECISION TO INTRODUCE 'THE EXPECTED LOSS MODEL' UNDER IFRS 9 CONTRIBUTE TO GREATER TRANSPARENCY OF FINANCIAL STATEMENTS

INFORMATION? IS IT TRUE OR IS IT TOO EARLY TO ADDRESS THE QUESTION?.

Hristina Oreshkova 
Mykola Gorodysky

Hanna Khomenko

Olena Syvak

MULTIPLE REVENUE STREAMS MODEL OF WINERIES

Katarína Remeňová

Nadežda Jankelová

INVESTMENTS IN REPAIR OF OUTDATED METAL FORMING MACHINES AND

EVALUATION OF THIS INVESTMENTS. 230

Burim Fejzaj

Milan Vukcević

Mileta Janjić

IMPACT OF FINANCIAL STRUCTURE ON ECONOMIC RETURN (ROA RETURN ON ASSET); CASE STUDY: WHOLESALE OF MOTOR VEHICLE PARTS AND ACCESSORIES (NACE: 4531).

Rodica Baciu (Boanta)

Petre BREZEANU

COMPARATIVE RISK ANALYSIS OF HUNGARIAN AND ROMANIAN TRADE AND SERVICE COMPANIES

Tibor Tarnóczi

Edina Kulcsár

CONTEMPORARY APPROACH TO THE ANALYSIS OF THE PURCHASING FUNCTION IN THE PRODUCTION COMPANY

Miroslav Cavlin

Radivoj Prodanovic

Pavle Pocuc

THE ROLE OF FIXED ASSETS IN THE DEVELOPMENT OF BUSINESS ACTIVITIES OF THE ORGANIZATION

Vuk Bevanda

Aleksandra Živaljević

Sara Stanić Jovanović

COMPARISON OF THE USE OF METHODS FOR INCREASING THE QUALITY

AND PERFORMANCE OF PROCESSES IN THE SLOVAK ECONOMY. 282

Pavol Gejdoš

Lubica Simanová 
THE PROSPECTS FOR IMPLEMENTATION OF BLOCKCHAIN TECHNOLOGY

IN THE HOUSING SECTOR OF THE RUSSIAN FEDERATION

Stanislav Viktorovich Pridvizhkin

Ulyana Petrovna Degtyareva

CONSUMER PERCEPTIONS TOWARDS CRYPTO CURRENCIES 299

Ismail Metin

Enis Yakut

VARIETY OF THE BENEFICIAL OWNERSHIP CONCEPT 310

Sonja Cindori

Toni Janković

STRATEGIC COHERENCE AS AN ORGANIZATIONAL ADJUSTMENT PROCESS

- CONCEPT AND MEASUREMENT OF THE PHENOMENON. 316

Paweł Mielcarek

INTERDISCIPLINARY UNDERSTANDING OF A CRISIS: TOWARDS AN INTERNATIONAL CRISIS CLASSIFICATION MATRIX

Albena Björck

AN EMPIRICAL INVESTIGATION OF SCHOOL TO WORK TRANSITION USING THE GOMPERTZ MODEL

Ana Gorenca

DEVELOPING A PROJECT MANAGEMENT CULTURE IN INSTITUTIONS OF HIGHER LEARNING

Daniel Seelhofer

Christian Olivier Graf

Selina Guhl

EDUCATION FOR SUSTAINABLE DEVELOPMENT IN SERBIA AT THE ONSET

OF THE FOURTH INDUSTRIAL REVOLUTION 354

Biljana Jovanović Gavrilović

Biljana Radivojević

COMPARATIVE PECULIARITIES OF THE LABOUR MARKET OF YOUNG SPECIALISTS IN RUSSIAN AND CHINA IN THE LAST DECADE

Evgeniya Yazovskikh

Zhao Qiogyu

THE SUCCESS OF PEER REVIEW EVALUATION IN UNIVERSITY RESEARCH FUNDING - THE CASE STUDY FROM SLOVAKIA

Alexandra Lešková

THE LEVEL AND POSITION OF STRATEGIC BUSINESS MANAGEMENT IN THE CZECH REPUBLIC, RUSSIA AND CHINA AND THEIR MUTUAL COMPARISON 
Jarmila Straková

PREDICTION OF THE DEVELOPMENT OF THE CORPORATE ENVIRONMENT IN THE CZECH REPUBLIC FROM THE PERSPECTIVE OF TOP MANAGERS . 392 Jan Váchal

THE ROLE OF MANAGEMENT IN MANAGEMENT OF COMPANIES 401

Nevenka Nićin

Anka Bulatović

Vojislava Grbić

MANAGEMENT PROFESSIONALIZATION AS CONDITION FOR MODERNIZATION OF COMPANIES' MANAGEMENT DUE TO APPLICATION OF A PARTICIPATIVE DEMOCRATIC DECISION MAKING MODEL

Valentina Vukosavljevic Pavlovic

TALENT MANAGEMENT IMPLEMENTATION IN ACTIVITIES OF HUMAN RESOURCE MANAGEMENT .

Julija Avakumovic

HUMAN RESOURCES AND THEIR PREPARATION IN THE SPHERE OF ENVIRONMENTALLY ORIENTED CRISIS MANAGEMENT IN THE CONTEXT OF A CIRCULAR ECONOMY.

Jaroslav Bednárik

CHALLENGES IN FORMULATING AND IMPLEMENTING OF STRATEGIC HUMAN RESOURCE MANAGEMENT

Denada Olli

A STUDY TOWARDS THE VERIFICATION OF FACTOR ANALYSIS WITH MULTIDIMENSIONAL SCALING: MEYER AND ALLEN'S ORGANIZATIONAL COMMITMENT SCALE

Aslı Beyhan Acar

Nil Selenay Erden

COMPARISON BETWEEN MNCS AND DOMESTIC COMPANIES ON TRAINING AND DEVELOPING EMPLOYEES IN SERBIAN CONTEXT

Marko Slavkovic

Marijana Simic

MANAGER, MANAGERIAL STRESS AND SPORTS RECREATION 453

Ivica Nikolić

Jova Miloradić

THE INTERNSHIP, A CHANCE FOR COMPANIES, BUT ESPECIALLY FOR STUDENTS.

Marius Calin BENEA 
SALES PROMOTION IN THE FUNCTION OF CREATING CONSUMER SATISFACTION AND INFLUENCING CONSUMER ATTITUDES

Marina Guzovski

Mirko Smoljić

Marina Stanić

BEHAVIOURAL FACTORS TO ANALYZE THE READINESS FOR INDIVIDUAL

CONSUMPTION

Maya Tsoklinova

Konstantin Kolev

ANALYSIS OF THE CONNECTION BETWEEN TELEVISION COMMERCIALS

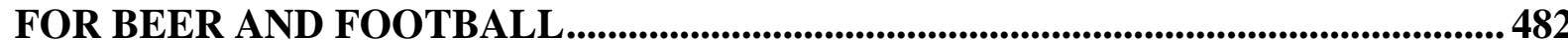

Nikola Vukčević

Luka Rakojević

APPLICATION OF SOCIAL NETWORKS IN EVERYDAY LIFE IN BOSNIA AND HERZEGOVINA

Zvezdan Stojanović

Fuad Hasanović

THE ROLE OF THE SOCIAL MEDIA IN THE TRADITIONAL MEDIA

DEVELOPMENT IN ALBANIA

Holta Heba

POSSIBILITIES OF USING EDULARP IN EDUCATION IN SLOVAK REPUBLIC 506

Adriana Grenčíková

Dagmar Petrušová

Karol Krajčo

THE ROLE OF WOMEN IN THE CREATION OF KNOWLEDGE FOR THE FOURTH INDUSTRIAL REVOLUTION

Marijana Vidas-Bubanja

Snežana Popovčić-Avrić

Iva Bubanja

DEPENDENCE OF QUANTITATIVE MODELS OF MANAGEMENT ON IOT AND

DIGITAL TRANSFORMATION

Milos Loncar

Marina Jovanovic Milenkovic

Milos Trkulja

STUDY ON THE DIGITIZATION LEVEL OF ROMANIAN ENTERPRISES . 534

Catalin Gheorghe 
SUSTAINABLE MARKETING STRATEGY - THE WAY TO GAIN PROFITS ON

INTERNATIONAL MARKETS

Saša Virijević Jovanović

Vesna Pijevac

Vesna Filipović

THE USE OF TWITTER AS A MARKETING TOOL BY TOUR OPERATORS IN

ANTALYA

Nur Undey Kalpaklioglu

Egemen Gunes Tukenmez

OECD MEMBERSHIP CHALLENGES FOR CROATIAN TOURISM;

SUSTAINABLE PERSPECTIVES

Jasmina Gržinić

ANALYSIS AND FORECAST OF TOURIST NIGHTS IN CROATIA BY $2022 \ldots . . . . .567$

Justin Pupavac

Antonio Badurina

EXPLORING CONNECTIONS BETWEEN CULTURAL HERITAGE, TOURISM

AND SUSTAINABLE DEVELOPMENT: THE CASE OF ROMANIA. 575

Călin Vegheș

MANAGING DIVERSITY IN THE HOSPITALITY INDUSTRY OF SLOVENIA.... 582 Marija Rok

HUMAN RESOURCE MANAGEMENT IN HOSPITALITY, RESTAURANTS AND

TRAVEL AGENCIES 592

Goran Pavlović

Nevena Vrcelj

NETWORK AND KNOWLEDGE SYSTEMS IN INDUSTRIAL AND TOURISM

CLUSTERS 599

Tülay GÜZEL

Tarık YALÇINKAYA

EXAMPLES OF EUROPEAN TOURISM DESTINATIONS AND IMPORTANCE OF AGRICULTURAL LANDSCAPES

Anita Silvana Ilak Peršurić

HISTORICAL DESTINATIONS IN NORTH INDIA AND THEIR IMPACTS: AN ANALYTICAL STUDY (SPECIAL FOCUS ON DELHI) 616

Zeba Zarin Ansari

Ajay Kumar

Anton Vorina 
SUSTAINABLE TOURISM IN THE PROTECTED AREAS OF BOSNIA AND HERZEGOVINA ON THE EXAMPLE OF THE NATURE MONUMENT "VRELO BOSNE"

Emir Temimović

DISTRIBUTION CHANNELS IN TOURISM IN THE MODERN APPROACH.........644

Cuneyt MENGU

TO BE MACHO OR NOT TO BE THAT'S THE MATTER: BANKING AND

TOURISM SECTORS

Ekrem Tufan

Sezer Deniz

İrem Ceylan Karagöz

Erhan Eren

Duygu Nedret Tüter

MASS MIGRATION - THE FASTEST GROWING CHALLENGE OF THE

EUROPEAN UNION WITH SPECIAL REFERENCE TO CROATIA. 665

Sanja Knežević

Anita Kulaš Mirosavljević

Lena Duspara

HOW THE LIFESTYLE AND STYLE OF THINKING OF THE ROMANIANS HAS

CHANGED 100 YEARS AFTER THE GREAT UNION

Marius Calin BENEA

YOU ARE WHAT YOU PERCEIVE AND EAT

Ekrem Tufan

Atila Yüksel

Funda Eriş

Aydan Taştan

ONE SOLUTION OF INTERACTION WEB APPLICATION FOR USERS

INTERCONNECTION 685

Nenad Kojić

Mustafa Levent

Natalija Vugdelija

THE NECESSITY OF APPLYING THE ECONOMY OF HARM AND BENEFIT OF EXPLOITATION OF ELECTRIC VEHICLES.

Nada Kosanovic

Danijela Rakic 
Anisa Myrtaj (Rexhepi)

Ilirjan Malollari

Luljeta Pinguli

MONITORING OF ENVIRONMENTAL CONDITIONS IN THE REPUBLIC OF SERBIA AND APPLICATION OF THE POLLUTER PAYS PRINCIPLE. 708

Milan Počuča

Jelena Matijašević-Obradović

EFFICIENT USE OF ENERGY AN IMPORTANT APPROACH IN MINIMIZING ENVIRONMENT AND OPERATIONAL COSTS IN ALBANIAN BREWERIES ..... 715

Luljeta Pinguli

Ilirjan Malollari

Lorina Lici

Jonilda Llupa

DEVELOPMENT AND APPLICATION OF POTENTIAL ALTERNATIVE ENERGY SOURCES

Goca D. Jovanović

Slavko Božilović

THE RAPESEED CULTURE EVOLUTION IN ROMANIA IN THE CONTEXT OF

CLIMATE CHANGE 728

Camelia Slave

Diana Vască Zamfir

THE COMPARISON OF REQUIREMENTS FOR A DISCLOSURE OF NONFINANCIAL INFORMATION ACCORDING TO LEGAL REGULATIONS IN SLOVAKIA AND EU DIRECTIVES

Renáta Pakšiová

CRIMINAL OFFENSES AGAINST SECURITY OF COMPUTER DATA IN THE REPUBLIC OF SRPSKA ACCORDING TO THE CRIMINAL LAW OF 2017 ......... 746

Miodrag N. Simović

Dragan Jovašević

Vladimir M. Simović

LEGAL FRAMEWORK FOR RESISTANCE OF SPORTS FAN VIOLENCE (FOOTBALL) - EVENTS IN MONTENEGRO

Željko Spalević

Ljubiša Konatar

Žaklina Spalević 
MEDIA TRIAL VS. FAIR TRIAL: ARE THE NEW MEDIA RESHAPING

ADMINISTRATION OF JUSTICE?

Tulishree Pradhan

Shuvro Prosun Sarker

BUSINESS COMPANIES IN KOSOVO 772

Majlinda Belegu

EQUALITY AND CHALLENGES IN EMPLOYMENT RELATIONSHIP BASED ON

KOSOVO LEGAL RESOURCES 781

Bashkim Rrahmani

GROUNDS AND PROCEDURE OF CHALLENGE OF ARBITRATORS IN

INTERNATIONAL ARBITRATION.

Mohammed Zaheeruddin

HUMAN TRAFFICKING FOR LABOUR EXPLOITATION AND THE ROLE OF WORK INSPECTION

Aleksandra Jovanović

Irena Šljivar Milijić

TRAFFICKING WITH HUMAN BEINGS, IDENTIFICATION AND THE

PRINCIPLES OF NON PUNISHMENT FOR VICTIMS OF TRAFFICKING 808

Veton Vula

YEKATERINBURG AGGLOMERATION: ANALYSIS OF THE CITY-PLANNING AND REAL ESTATE MARKET SITUATION IN THE SEGMENT OF APARTMENT

BUILDINGS IN VERKHNYAYA PYSHMA.

Anna Loginova

Stanislav Pridvizhkin

ANALYSIS OF THE RISKS GENERATED BY CONCEALED WORKS IN THE FIELD OF CONSTRUCTION

Lidia NICULIȚĂ

Laurenţiu RECE

Andreea Dora Bianca PIRONEA

MODULAR PRECAST METALLIC BALCONIES FOR BUILDINGS AND

PROCESSES FOR MAKING THE SAME 840

Laurentiu RECE

Dragos VOICULESCU

Andreea Dora Bianca PIRONEA

COMPARATIVE ANALYSIS OF THE SHEAR FORCE RESISTANCE OF WELDED STEEL SECTIONS WITH FLAT WEBS TO CORRUGATED WEBS STEEL CROSS SECTIONS.

Daniel Taus 


\section{Dorin Radu}

EVALUATION OF STEADY-STATE OPERATION OF ENVIRONMENTAL CLIMATIC CHAMBER MEASURING TEMPERATURE AND RELATIVE HUMIDITY. 858

Iska Kolaveri Spahiu

Dhurata Premti

Floran Vila

Anisa Dhroso

PERFORMANCE EVALUATION OF AN EXPERIMENTAL SYSTEM MEASURING

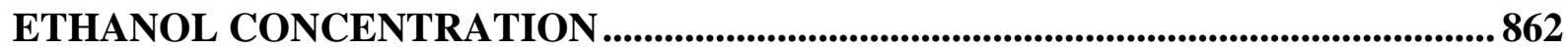

Erinda Piluri

Hasime Manaj

Ilirjan Malollari

Irakli Premti

THE FACTORS AFFECTING THE TREND OF FDI-S IN ALBANIA DURING THE LAST 5 YEARS.

Blerta Dragusha

Erjola Barbullushi (Sakti)

CROWDFUNDING AND SOCIAL RESPONSIBILITY: CREATING ECONOMIC VALUE AND SOCIAL VALUE

Nadia Oliva

THE STRUCTURE OF MARGINAL COSTS: A PEDAGOGICAL REVIEW 869

Petar Stankov

ANALYSIS OF THE STRUCTURE OF BANK RECEIVABLES FROM THE

BUSINESS SECTOR IN THE REPUBLIC OF SERBIA

Dragana Tadić Živković

ALTMAN Z-SCORE REVISED MODELS AS EARLY WARNING SYSTEMS FOR

BANKRUPTCY EVALUATION OF ECONOMIC ENTITIES .

Erjole Barbullushi

Blerta Dragusha

NON-FINANCIAL BACKGROUND OF FINANCIAL PERFORMANCE: EVIDENCE

FROM CENTRAL AND EASTERN EUROPE

Gyorgy Andor

Tamas Toth

ENTERPRISE ARCHITECTURE AS A FACTOR TO ELIMINATE IMPACTS IN ENTERPRISE EXTERNAL ENVIRONMENT 875

Petra Pártlová 
Jan Váchal

THE 40\% CLUB: COMPANY PERFORMANCE QUALITY AND GENDER

EQUALITY.

Brikena Berisha

CORPORATE GOVERNANCE AND PERFORMANCE OF SME SECTOR IN KOSOVO

Saxhide Mustafa

CORPORATE SUSTAINABILITY: VALUE CREATION IN SUSTAINABLE

MANUFACTURING 880

Damla Ozekan

CHANGING ROLE OF CFOS 882

Sinan Cifci

UNBUNDLING THE ROLES OF INSTITUTIONS AND HUMAN CAPITAL IN

DEVELOPMENT: A GLOBAL EVIDENCE. 883

Soner Gokten

Furkan Baser

Pınar Okan Gokten

THE IMPACT OF HUMAN CAPITAL ON SUSTAINABLE GROWTH - THE CASE

OF REPUBLIC OF MACEDONIA 884

Slagjana Stojanovska

Violeta Madzova

Margarita Matlievska

LEADERSHIP EFFECTIVENESS IN MODERN AGE 885

Vuk Mirčetić

Pavle Brzaković

Svetlana Vukotić

GOOD ORGANIZATIONAL GOVERNANCE AND DEVELOPMENT OF

LEADERSHIP SKILLS IN SPORTS 886

Danica Pirsl

Andon Kostadinovic

MANIFESTATIONS AND SIGNIFICANCE OF "WORK EXPERIENCE" IN THE ORGANIZATION. 888

Mária Héder

SUSTAINABLE MARKETING AS A COMPETITIVE ADVANTAGE AND A CASE STUDY ON GLASS SECTOR IN TURKEY

Evrim Ildem Develi

ACCESS AND METHODS OF MARKETING RESEARCH. 891 
Dina Lazarević

Nevena Ćurić

Katarina Radlovački

SIGNIFICANCE OF SOCIAL MEDIA MARKETING 893

Milena Sretić

Nemanja Stojković

Željko Ondrik

THE INFLUENCE OF THE EXTERNAL ENVIRONMENT ON THE FORMULATION OF MARKETING STRATEGY 895

Katarina Radlovački

Željko Ondrik

Nemanja Stojković

INTEGRATING CLOUD ENABLED SMART TECHNOLOGIES INTO EVENT

MANAGEMENT. 896

Saha Baygul Ozpinar

Alper Ozpinar

OFF-ROAD TOURISM: AN ALTERNATIVE WAY FOR SUSTAINABLE TOURISM

IN ÇANAKKALE, TURKEY 898

Figen SEVINÇ

Erol DURAN

INFORMATION AND COMMUNICATION TECHNOLOGIES IN SERBIA:

GROWTH AND UNEVEN SPATIAL DEVELOPMENT 899

Aljoša Budović

Vojislav Deđanski

EVALUATION OF INNOVATIVE ENTREPRENEURSHIP ECOSYSTEM:

TECHNOLOGY AUDIT. 901

Mehmet Şahin Gök

Erşan Ciğerim

Tuğkan Arıcı

ADAPTING A COMPANY'S STRATEGY IN THE DIGITAL TRANSFORMATION

ERA 902

Christian Tanushev

BLACK BOX OF INDUSTRY 4.0: NEW OPPORTUNITIES FOR ENTREPRENEURSHIP ECOSYSTEM 903

Erşan Ciğgerim

Tuğkan Arıcı

Mehmet Şahin Gök 
IMPROVING TEACHING USING A GAME ENGINE 904

Natalija Vugdelija

Nenad Kojić

Nikola Mihajlović

CONTRACT ON GIVING INFORMATION AND ADVICE (CONSULTING CONTRACT). 906

Mario Vojnić Hajduk

CROSS-BORDER UNFAIR COMPETITION CASES IN ONLINE ENVIRONMENT THE EU CONFLICT-OF-LAWS PERSPECTIVE IN TERMS OF LEGAL

CERTAINTY AND PREDICTABILITY 908

Iveta Rohová

EUROPEAN BUSINESS EXCELLENCE MODEL ON SUSTAINABLE

DEVELOPMENT. 910

Vesna Miladinović

Katarina Lazović 


\section{Index of Authors}

\section{A}

Adriana Grenčíková, 506

Aglika Kaneva, 86

Ajay Kumar, 616

Albena Björck, 323

Aleksandra Jovanović, 802

Aleksandra Živaljević, 273

Alexandra Lešková, 372

Alper Ozpinar, 896

Aljoša Budović, 899

Ana Gorenca, 330

Andon Kostadinovic, 886

Andreea Dora Bianca PIRONEA, 824, 840

Anisa Dhroso, 858

Anisa Myrtaj (Rexhepi), 701

Anita Kulaš Mirosavljević, 665

Anita Silvana Ilak Peršurić, 606

Anka Bulatović, 401

Anna Loginova, 817

Anton Vorina, 616

Antonio Badurina, 567

Arsen Benga, 137

Aslı Beyhan Acar, 438

Atila Yüksel, 679

Aydan Taştan, 679

\section{B}

Bashkim Rrahmani, 781

Biljana Jovanović Gavrilović, 354

Biljana Petrevska, 40

Biljana Radivojević, 354

Blerta Dragusha, 866, 873

Brikena Berisha, 877

Burim Fejzaj, 230

\section{C}

Călin Vegheș, 575

Camelia Slave, 728

Catalin Gheorghe, 534

Christian Olivier Graf, 340

Christian Tanushev, 902

Cuneyt MENGU, 644
D

Dagmar Petrušová, 47, 506

Dagmar Škodová Parmová, 65

Damla Ozekan, 880

Danica Pirsl, 886

Daniel Seelhofer, 340

Daniel Taus, 851

Danijela Rakic, 692

Denada Olli, 430

Dhurata Premti, 858

Diana Vască Zamfir, 728

Dijana Grahovac, 55

Dina Lazarević, 891

Dorin Radu, 851

Dragan Jovašević, 746

Dragana Tadić Živković, 872

Dragos VOICULESCU, 840

Duygu Nedret Tüter, 657

\section{E}

Edina Kulcsár, 252

Egemen Gunes Tukenmez, 551

Ekrem Tufan, 657, 679

Emir Temimović, 637

Enis Yakut, 299

Erhan Eren, 657

Erinda Piluri, 862

Erjola Barbullushi (Sakti), 866

Erjole Barbullushi, 873

Erol DURAN, 898

Erşan Ciğerim, 901, 903

Evgeniya Yazovskikh, 361

Evrim Ildem Develi, 889

\section{F}

Figen SEVİNÇ, 898

Flamur Keqa, 160

Flamur Mrasori, 176

Floran Vila, 858

Forcim Kola, 125

Fuad Hasanović, 489

Funda Eriş, 679

Furkan Baser, 883 


\section{G}

Glediana Zeneli, 137

Goca D. Jovanović, 724

Goran Pavlović, 592

Gyorgy Andor, 22, 874

\section{H}

Hanna Khomenko, 211

Hasime Manaj, 862

Holta Heba, 497

Hristina Oreshkova, 195

I

Ilirjan Malollari, 701, 715, 862

Irakli Premti, 862

İrem Ceylan Karagöz, 657

Irena Lekoska, 169

Irena Šljivar Milijić, 802

Iska Kolaveri Spahiu, 858

Ismail Metin, 299

Iva Bubanja, 513

Iva Raycheva, 35

Iveta Rohová, 908

Ivica Nikolić, 453

Iwona Olejnik, 115

\section{$\mathbf{J}$}

Jan Váchal, 392, 875

Jana Sochul'áková, 47

Jarmila Straková, 383

Jaroslav Bednárik, 424

Jasmina Gržinić, 560

Jelena Matijašević-Obradović, 708

Jonilda Llupa, 715

Jova Miloradić, 453

Julija Avakumovic, 415

Justin Pupavac, 567

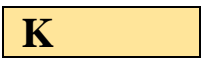

Karol Krajčo, 506

Katarína Králová, 47

Katarina Lazović, 910

Katarina Radlovački, 891, 895

Katarína Remeňová, 222

Konstantin Kolev, 474
$\mathbf{L}$

Landi Gushi, 97

Laurențiu RECE, 824

Laurentiu, RECE, 840

Lena Duspara, 665

Lidia NICULIȚĂ, 824

Lorina Lici, 715

L’ubica Simanová, 282

Luka Rakojević, 482

Luljeta Pinguli, 701, 715

Ljubiša Konatar, 752

\section{M}

Magdalena Stefańska, 115

Majlinda Belegu, 772

Margarita Matlievska, 884

Mária Héder, 888

Marija Rok, 582

Marijana Simic, 447

Marijana Vidas-Bubanja, 513

Marina Gajic Glamoclija, 16

Marina Guzovski, 466

Marina Jovanovic Milenkovic, 521

Marina Stanić, 466

Mario Vojnić Hajduk, 906

Marius Calin BENEA, 460, 673

Marko Slavkovic, 447

Mary Ellen Toffle, 2

Maya Tsoklinova, 474

Mehmet Șahin Gök, 901, 903

Milan Počuča, 708

Milan Vukcević, 230

Milena Sretić, 893

Mileta Janjić, 230

Milos Loncar, 521

Milos Trkulja, 521

Miodrag N. Simović, 746

Mirko Smoljić, 466

Miroslav Cavlin, 266

Mohammed Zaheeruddin, 789

Monika Vámošová, 79

Mustafa Levent, 685

Mykola Gorodysky, 211

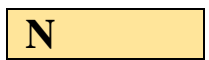

Nada Kosanovic, 692

Nadežda Jankelová, 222 
Nadia Oliva, 868

Natalija Vugdelija, 685, 904

Nemanja Stojković, 893, 895

Nenad Kojić, 685, 904

Nevena Curić, 891

Nevena Vrcelj, 592

Nevenka Nićin, 401

Nikola Mihajlović, 904

Nikola Vukčević, 482

Nikolay Atanasov, 106

Nil Selenay Erden, 438

Nur Undey Kalpaklioglu, 551

\section{$\mathbf{O}$}

Olena Syvak, 211

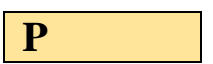

Pavle Brzaković, 885

Pavle Pocuc, 266

Pavol Gejdoš, 282

Paweł Mielcarek, 316

Petar Stankov, 869

Petra Pártlová, 875

Petre BREZEANU, 237

Pınar Okan Gokten, 883

\section{$\mathbf{R}$}

Radivoj Prodanovic, 266

Renáta Pakšiová, 736

Rodica Baciu (Boanta), 237

Rostislav Kain, 65

\section{$\mathbf{S}$}

Saha Baygul Ozpinar, 896

Sanja Knežević, 665

Sara Stanić Jovanović, 273

Saša Virijević Jovanović, 542

Saxhide Mustafa, 879

Selina Guhl, 340

Senad Softić, 55

Sezer Deniz, 657

Shkendije Nahi, 176

Shuvro Prosun Sarker, 764

Sinan Cifci, 882

Slagjana Stojanovska, 884
Slavko Božilović, 724

Snežana Popovčić-Avrić, 513

Soner Gokten, 883

Sonja Cindori, 310

Stanislav Pridvizhkin, 817

Stanislav Viktorovich Pridvizhkin, 292

Svetlana Vukotić, 885

\section{$\mathbf{T}$}

Tamas Toth, 874

Tarık YALÇINKAYA, 599

Tatjana Boshkov, 185

Teuta Cerpja, 125

Tibor Tarnóczi, 252

Toni Janković, 310

Tuğkan Arıcı, 901, 903

Tülay GÜZEL, 599

Tulishree Pradhan, 764

\section{$\mathbf{U}$}

Ulyana Petrovna Degtyareva, 292

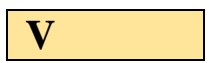

Valentina Vukosavljevic Pavlovic, 409

Vesna Filipović, 542

Vesna Miladinović, 910

Vesna Pijevac, 542

Veton Vula, 808

Violeta Madzova, 884

Vladimir M. Simović, 746

Vojislav Deđanski, 899

Vojislava Grbić, 401

Vuk Bevanda, 273

Vuk Mirčetić, 885

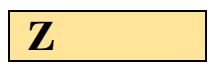

Zarko Radjenovic, 185

Zeba Zarin Ansari, 616

Zhao Qiogyu, 361

Zuzana Dvořáková Líšková, 65

Zvezdan Stojanović, 489

Žaklina Spalević, 752

Željana Vrućinić, 147

Željko Ondrik, 893, 895

Željko Spalević, 752 
Economic development refers to the improvement of activities in the economy, which leads to progressive changes in the socio-economic structure and the rising of living standards. Given that the objective of sustainable economic development is elimination of poverty, inequality and unemployment - thus leading to social inclusion and improvement of the quality of life; it is necessary in analysis of this important issue apply extremely multidisciplinary approach.

Faculty of Business Studies, Mediterranean University - Podgorica, Montenegro; University of National and World Economy - Sofia, Bulgaria; Faculty of Commercial and Business Studies Celje, Slovenia; Faculty of Applied Management, Economics and Finance - Belgrade, Serbia and the Association of Economists and Managers of the Balkans have recognized following issue and organized in Sofia on June 7, 2018 at the Sofia City Hotel Fourth International Scientific Conference titled: Knowledge based sustainable economic development - ERAZ 2018.

The conference objective was to bring together academic community (experts, scientists, engineers, researchers, students and others) and publication of their scientific papers for the purpose of popularization of science and their personal and collective affirmation. The unique program combined interactive discussion and other forms of interpersonal exchange of experiences and presentation of the latest scientific developments in following areas.

- Microeconomics and macroeconomics,

- Economic policy,

- International Economics and Trade,

- International Business,

- Economic diplomacy,

- Lobbying,

- Globalization,

- European business,

- Modern management and innovation,

- Business and Public Finance,

- Fiscal policy,

- Stock exchange and financial markets,

- Risk management,

- Insurance and reinsurance companies,

- Financial Management and Banking,

- Modern forms of entrepreneurship and investment,

- Investment Management,

- Enterprise and Learning,

- Women and Entrepreneurship,
- Corporate entrepreneurship,

- Agribusiness Strategy,

- Marketing and trade,

- Marketing services,

- Marketing of non-profit sector,

- Research in marketing,

- Marketing in education,

- Marketing in sport,

- Marketing in culture,

- Accounting and auditing,

- Quality management,

- Labor law,

- Business law,

- The role of the rule of law in the country's progress,

- Human rights and protection of minorities,

- Legal aspects of EU integration,

- Intellectual Property Law,

- The reform of corporate law in countries in transition,

- CEFTA,

- Ecology and energy,

- Renewable energy,

- Energetic efficiency, 
- Information technology and business intelligence,

- The use and integration of new technologies,

- E-society and E-learning,

- Sustainable tourism,

- Hospitality

In the Conference Proceedings of the ERAZ 2018 conference 97 papers and 30 abstracts have been published on more than 900 pages.

Participation in the conference took 227 researchers with the paper representing:

- 21 different countries,

- 80 different universities,

- 69 eminent faculties,

- 8 scientific institutes,

- 17 colleges,

- various ministries, local governments, public and private enterprises, multinational companies, associations, etc.

1. Albania

2. Bosnia and Herzegovina

3. Bulgaria

4. Croatia

5. Czech Republic

6. Greece

7. Hungary

8. India

9. Italy

10. Kuwait

11. Macedonia

12. Montenegro

13. Poland

14. Romania

15. Russia

16. Serbia

17. Slovakia

18. Slovenia

19. Switzerland

20. Turkey

21. Ukraine
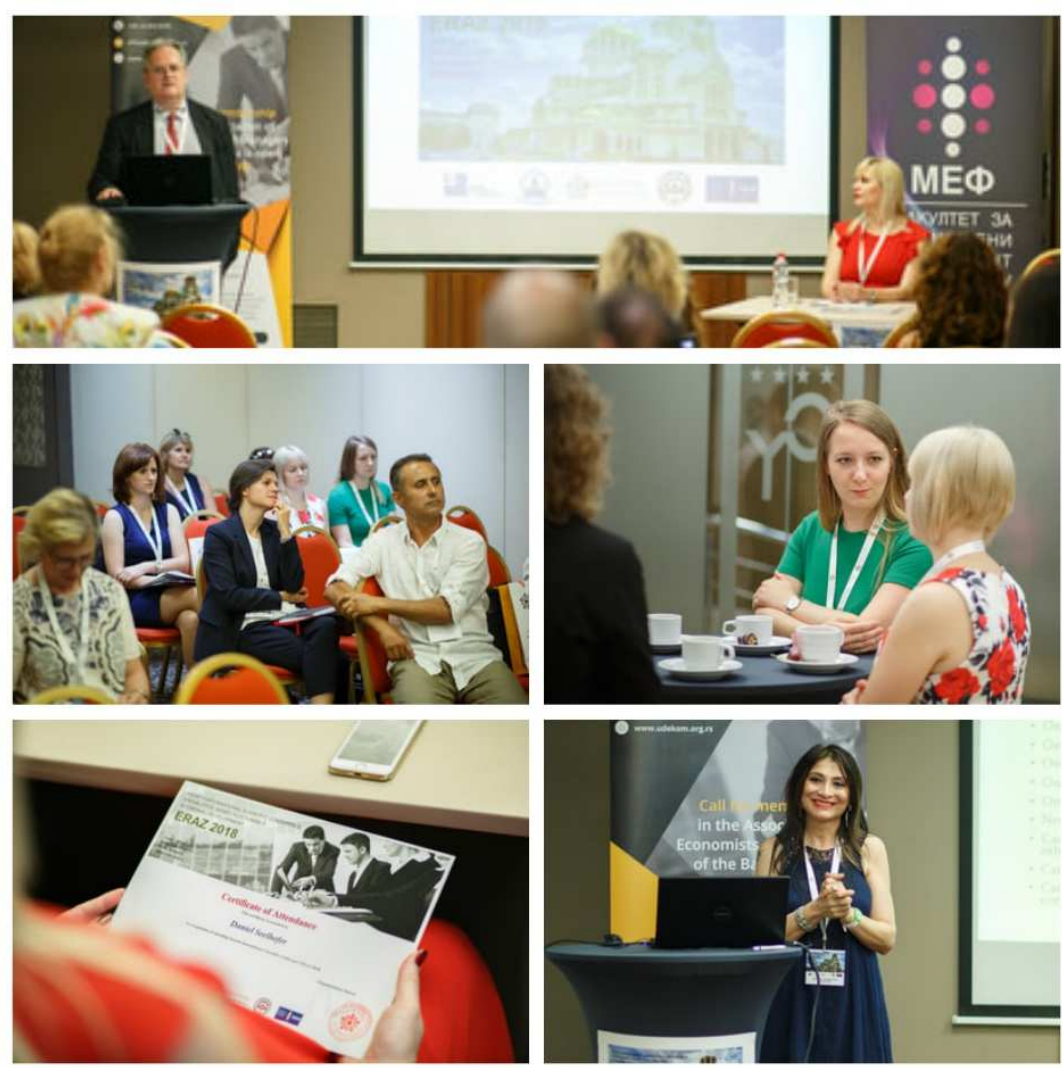


\section{Participating Universities:}

1. Adnan Menderes University, Kuşadası, Turkey

2. Aleksandër Moisiu University of Durrës, Durrës, Albania

3. Alexander Dubček University, Trenčín, Slovakia

4. Alfa University, Belgrade, Serbia

5. American University of the Middle East, Kuwait

6. Ankara University, Ankara, Turkey

7. Balıkesir University, Balıkesir, Turkey

8. Bartın University, Turkey

9. Baskent University, Ankara, Turkey

10. Bucharest University of Economic Studies, Bucharest, Romania

11. Çanakkale Onsekiz Mart University, Çanakkale, Turkey

12. Educons University, Sremska Kamenica, Serbia

13. Eotvos Lorand University, Budapest, Hungary

14. Epoka University, Tirana, Albania

15. European University Brčko District, Bosnia and Herzegovina

16. European University of Tirana, Albania

17. Galatasaray University, Istanbul, Turkey

18. Gazi University, Ankara, Turkey

19. Gebze Technical University, Kocaeli, Turkey

20. Goce Delcev University - Shtip, Macedonia 21. Halic University, Istanbul, Turkey

22. Independent University in Banja Luka, Bosnia and Herzegovina

23. International Balkan University, Skopje, Macedonia

24. Istanbul Commerce University, Istanbul, Turkey

25. Istanbul Kultur University, Istanbul, Turkey

26. Istanbul University, Istanbul, Turkey

27. Jamia Millia Islamia University, Delhi, India

28. Jawaharlal Nehru University, Delhi, India

29. Juraj Dobrila University, Pula, Croatia

30. Kallos University, Tuzla, Bosnia and Herzegovina

31. Manisa Celal Bayar University, Manisa, Turkey

32. Marin Barleti University, Tirana, Albania

33. Masaryk University, Czech Republic

34. Medical University - Plovdiv, Bulgaria

35. Megatrend University, Belgrade, Serbia

36. Metropolitan University, Belgrade, Serbia

37. MIT University -Skopje, Macedonia

38. Neumann Janos University, Hungary

39. Partium Christian University, Oradea, Romania

40. Politehnica University Timișoara, Hunedoara, Romania

41. Polytechnic University of Tirana, Albania

42. Poznań University of Economics and Business, Poznań, Poland

43. Technical University in Zvolen, Zvolen, Slovakia

44. Technical University of Civil Engineering Bucharest, Bucharest, Romania

45. Telematic University Giustino Fortunato; Benevento, Italy

46. Transilvania University of Braşov, Braşov, Romania 47. University "Fan S. Noli", Korce, Albania

48. University „Vitez“ Vitez, Bosnia and Herzegovina

49. University Business Academy, Novi Sad, Serbia

50. University of "Union - Nikola Tesla", Belgrade, Serbia

51. University of Agronomic Sciences and Veterinary Medicine of Bucharest, Bucharest, Romania

52. University of Banja Luka, Bosnia and Herzegovina

53. University of Belgrade, Serbia

54. University of Business Studies Banja Luka, Bosnia and Herzegovina

55. University of Debrecen, Hungary

56. University of Donja Gorica, Podgorica, Montenegro

57. University of Economics in Bratislava, Slovakia

58. University of Forestry, Sofia, Bulgaria 
59. University of Ioannina, Greece

60. University of Kragujevac, Serbia

61. University of Messina, Italy

62. University of National and World Economy, Sofia, Bulgaria

63. University of Nish, Serbia

64. University of Novi Sad, Serbia

65. University of Primorska, Portorož, Slovenia

66. University of Prishtina

67. University of Sarajevo, Bosnia and Herzegovina

68. University of Shkodra „Luigj Gurakuqi“, Shkoder, Albania

69. University of South Bohemia, České Budějovice, Czech Republic

70. University of Ss. Cyril and Methodius in Trnava, Slovakia

71. University of Tirana, Albania

72. University of Vlora, Albania

73. University of Zagreb, Croatia

74. University Singidunum, Serbia

75. University Ss. Cyril and Methodius, Skopje, Macedonia

76. Ural federal University named after the first President of Russia B. N. Yeltsin, Russia 77. Uskudar University, Istanbul, Turkey

78. WB National University of Juridical Sciences, Kolkata, India

79. Zhytomyr State Technological University, Zhytomyr, Ukraine

80. Zurich University of Applied Sciences, Winterthur, Switzerland

\section{Participating Faculties:}

1. Economic Faculty, University of Shkodra „Luigj Gurakuqi“, Shkoder, Albania

2. Faculty for Finance, Banking and Auditing, Alfa University, Belgrade, Serbia 3. Faculty Futura, Belgrade, Serbia

4. Faculty of Applied Management, Economics and Finance, Belgrade, Serbia

5. Faculty of Arts and Communications, University of Donja Gorica, Podgorica, Montenegro

6. Faculty of Business Economics, Educons University, Sremska Kamenica, Serbia

7. Faculty of Business Management, University of Economics in Bratislava, Slovakia 8. Faculty of Business Studies, Belgrade, Serbia

9. Faculty of Business, Manisa Celal Bayar University, Manisa, Turkey

10. Faculty of Civil Engineering, Transilvania University of Brașov, Brașov, Romania

11. Faculty of Corporate Strategy, České Budějovice, Czech Republic

12. Faculty of Culture and Media, University "Megatrend", Serbia

13. Faculty of Economic Informatics, University of Economics in Bratislava, Bratislava, Slovakia

14. Faculty of Economics and Business, Neumann Janos University, Budapest, Hungary

15. Faculty of Economics and Business, University of Debrecen, Hungary

16. Faculty of Economics and Engineering Management in Novi Sad, Serbia

17. Faculty of Economics and Social Science, Partium Christian University, Oradea, Romania

18. Faculty of Economics and Tourism "Dr. Mijo Mirković", Juraj Dobrila University, Pula, Croatia

19. Faculty of Economics, East Sarajevo, Bosnia and Hercegovina

20. Faculty of Economics, Sarajevo, Bosnia and Herzegovina

21. Faculty of Economics, University "Fan S. Noli", Korce, Albania

22. Faculty of Economics, University of Banja Luka, Bosnia and Herzegovina

23. Faculty of Economics, University of Belgrade, Serbia

24. Faculty of Economics, University of Kragujevac, Serbia

25. Faculty of Economics, University of Nish, Serbia

26. Faculty of Economics, University of South Bohemia, České Budějovice

27. Faculty of Economy, AAB College, Prishtinë

28. Faculty of Economy, University of Prishtina

29. Faculty of Economics, Univesity of Novi Sad, Subotica, Serbia

30. Faculty of Engineering and Technology, American University of the Middle East, Kuwait

31. Faculty of Engineering Hunedoara, Politehnica University Timişoara, Hunedoara, Romania

32. Faculty of Finance and Accounting, University of National and World Economy, Sofia, Bulgaria

33. Faculty of Geography, University of Belgrade, Belgrade, Serbia

34. Faculty of Geology and Mining, Polytechnic University of Tirana, Albania 
35. Faculty of Law for Commerce and Judiciary, University Business Academy, Sad, Serbia 36. Faculty of Law, Banja Luka, Bosnia and Herzegovina

37. Faculty of Law, Security and Management "Konstantin Veliki", University of "Union - Nikola Tesla", Belgrade, Niš, Serbia

38. Faculty of Law University „Vitez“, Vitez, Bosnia and Herzegovina

39. Faculty of Law, Masaryk University, Czech Republic 40. Faculty of Law, Niš, Serbia

41. Faculty of Law, University of Novi Sad, Serbia

42. Faculty of Law, University of Prishtina

43. Faculty of law, University of Zagreb, Zagreb, Croatia

44. Faculty of Management, Halic University, Istanbul Turkey

45. Faculty of Management, Poznań University of Business and Economics, Poznań, Poland

46. Faculty of Marketing, Bucharest University of Economic Studies, Romania

47. Faculty of Mass Media Communication, University of Ss. Cyril and Methodius in Trnava, Slovak republic

48. Faculty of Mechanical Engineering, Podgorica, Montenegro

49. Faculty of Natural Sciences and Mathematics, University of Sarajevo, Bosnia and Herzegovina

50. Faculty of Natural Sciences. University of Tirana, Albania

51. Faculty of Organizational Sciences, University of Belgrade, Serbia

52. Faculty of Political Science, Çanakkale Onsekiz Mart University, Çanakkale, Turkey

53. Faculty of Public Health, Medical University, Plovdiv, Bulgaria

54. Faculty of Security and Protection, Independent University in Banja Luka, Bosnia and Herzegovina

55. Faculty of Social and Economic Relations, Alexander Dubček University in Trenčín, Trenčín, Slovakia

56. Faculty of Sport, University of Nis, Serbia

57. Faculty of Strategic and Operational Management in Belgrade, Serbia

58. Faculty of Technical Sciences, University of Vlora, Vlore, Albania

59. Faculty of Tourism and Business Logistics, Goce Delcev University - Shtip, Macedonia

60. Faculty of Tourism and Hospitality Management, Opatija, Croatia

61. Faculty of Tourism Studies, University of Primorska, Portorož, Slovenia

62. Faculty of Tourism, Adnan Menderes University, Kuşadası, Turkey

63. Faculty of Tourism, Balıkesir University, Balıkesir, Turkey

64. Faculty of Tourism, Çanakkale Onsekiz Mart University, Çanakkale,Turkey

65. Faculty of Wood Sciences and Technology, Technical University in Zvolen, Zvolen, Slovakia

66. FEFA Faculty, Metropolitan University, Belgrade, Serbia

67. Integrated Business Faculty, Skopje, Macedonia

68. Iustinianus Primus Faculty of Law, University Ss. Cyril and Methodius, Skopje, Macedonia

69. Technical Faculty, Kallos University, Tuzla, Bosnia and Herzegovina

\section{Participating Institutes:}

1. Institute of Accounting and Finance, Debrecen, Hungary

2. Institute of Agriculture and Tourism, Poreč, Croatia

3. Institute of applied science in agriculture, Belgrade, Republic of Serbia

4. Institute of Business Economics, Budapest, Hungary

5. Institute of Technology and Business in České Budějovice, Czech Republic

6. International Management Institute, Zurich University of Applied Sciences, Winterthur, Switzerland

7. Riinvest - Institute for Development Research

8. Social Science Institute/Tourism Management, Canakkale Onsekiz Mart University, Turkey

\section{Colleges:}

1. Bartın Vocational school, Bartın University, Turkey

2. Belgrade Business School, Belgrade, Serbia

3. Çanakkale School of Applied Sciences, Çanakkale Onsekiz Mart University, Çanakkale, Turkey

$$
\text { 4. College AAB, Pristina }
$$

5. College of Applied Sciences "Lavoslav Ružička" in Vukovar, Vukovar; Croatia

6. College of Law, United Arab Emirates 
7. College of Slavonski Brod, Slavonski Brod, Croatia

8. Federal State Autonomous Educational Institution of Higher Professional Education "Ural Federal University named after the first President of Russia B.N. Yeltsin", Yekaterinburg, Russian Federation

9. High Business School of Vocational Studies Leskovac, Serbia

10. High school for tourism, Belgrade, Serbia

11. Higher Colleges of Technology, United Arab Emirates

12. ICT College for vocational studies, Belgrade, Serbia

13. Károly Ihrig Doctoral School of Management and Business, University of Debrecen, Hungary 14. KIIT School of Law, Odisha, India

15. School of Business, Istanbul University, Istanbul, Turkey

16. School of Management and Law, Zurich University of Applied Sciences, Winterthur, Switzerland 17. Vocational College, Celje, Slovenia

\section{Other Participating Institutions:}

Academy of Sciences and Art of Bosnia and Herzegovina; Academy of Sciences of Albania, Tiranë, Albania;

Central Bank of Kosovo; City Administration of Pančevo City, Serbia; Constitutional Court of Bosnia and Herzegovina; Edukos d.o.o., Banja Luka, Bosnia and Hercegovina; European Academy of Sciences and Arts; General Directorate of Metrology of Albania, Tirane, Albania; JKP „Beograd put“ - Belgrade, Serbia; Lab of

Food Chemistry, Department of Chemistry, University of Ioannina, Greece; Labor Inspection, Nis, Serbia; Mercan Tourism, Istanbul, Turkey; Ministry of finance, Tax administration, Split, Croatia; Prosecutor's Office of Bosnia and Herzegovina; Provincial Secretariat for Economy and Tourism of AP Vojvodina, Novi Sad, Serbia;

Russian Academy of Natural Sciences; Surčin Cultural Center, Surčin, Serbia
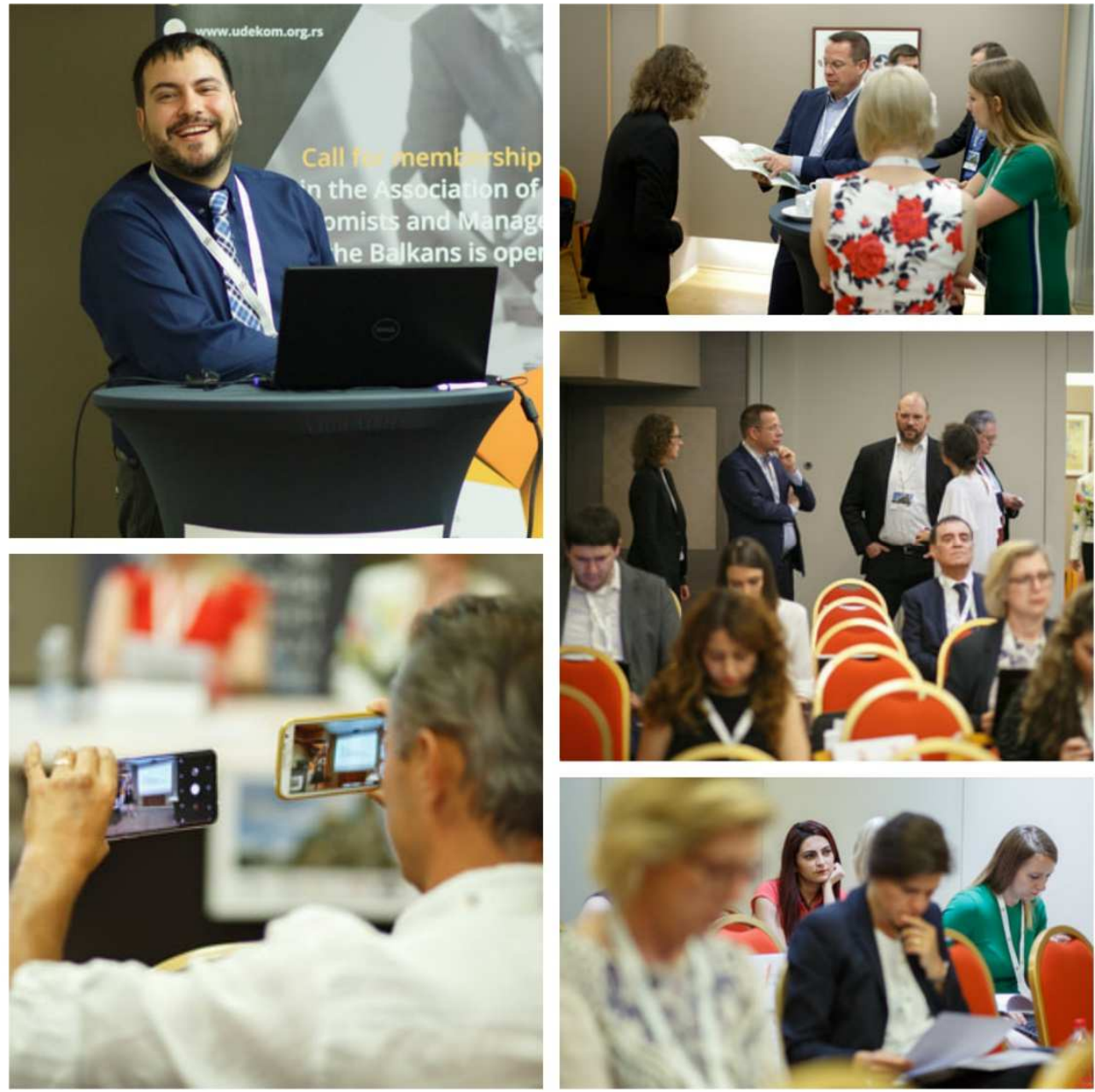


\title{
DEVELOPING E-BANKING PLATFORM IN CONTEMPORARY WORLD
}

\author{
Zarko Radjenovic ${ }^{107}$ \\ Tatjana Boshkov ${ }^{108}$
}

DOI: https://doi.org/10.31410/eraz.2018.185

\begin{abstract}
Banks play a crucial role in promoting online businesses. Banks are trustworthy intermediaries in the online transactions and they provide a bold opening in the online business. Banks have e-payment systems like Internet banking, electronic fund transfers, plastic money (credit card \& debit card) and mobile banking. These systems provide payment to online transactions. For the real working of these e-services, the need of e-banking platform development is an inevitable feature.

This paper examines the efficient utilization of developing e-banking platform which have all the infrastructures for availing the same. For this reason we explore the impact of systems factors for E- banking platform development (scalability, interoperability, fast server response, user-friendliness ect.), Organizational factors for E- banking platform development (multistakeholders perspective, bank image and resource allocation)and Economic factors (operational efficiency, administration costs, innovation diffusion, financial information assistance). The change of economy from a traditional way to the recently demanded form needs a huge technological support and effort, better planning and efficiency in implementation thus pushing the banks to design various electronic money products.
\end{abstract}

Key words: $e$-money, e-banking, platform, software alternatives.

\section{INTRODUCTION}

A well-functioning financial system plays a crucial role in the transformation process from a centrally- planned economy towards one that is market-oriented. It is essential that developing countries consider steps towards financial liberalization or deregulation, which will help open the borders for capital flows and attract new investments and ideas. While financial liberalization does not guarantee quick economic growth for developing countries, it helps increase the chances for progress and creation of opportunities for financial development. Developing countries have learned through their own history and the evidence from around the world that, in order to start liberalization processes, it is essential to first ensure adequate regulation of their financial systems in line with country-specific requirements and circumstances. It is often wrongly assumed that economies with greater connection and dependencies on international trade require stronger liberalization. It is important to recognize that, when it comes to financial systems and economy, each developing country follows their own practices, processes and traditions and should also find the most appropriate liberalization model that suits their circumstances.

Banks are intermediaries in the online transactions and they provide a bold opening in the online business. Banks have e-payment systems like Internet banking, electronic fund transfers, plastic

\footnotetext{
${ }^{107}$ Faculty of Economics, University of Nish, Serbia

${ }^{108}$ Faculty of Tourism and Business Logistics, Goce Delcev University - Shtip, Macedonia
} 
money (credit card \& debit card) and mobile banking. These systems provide payment to online transactions. For the real working of these e-services, the need of e-banking platform development is an inevitable feature.

This paper examines the efficient utilization of developing e-banking platform which have all the infrastructures for availing the same. For this reason we explore the impact of systems factors for E- banking platform development (scalability, interoperability, fast server response, user-friendliness ect.), Organizational factors for E- banking platform development (multistakeholders perspective, bank image and resource allocation) and Economic factors (operational efficiency, administration costs, innovation diffusion, financial information assistance). The change of economy from a traditional way to the recently demanded form needs a huge technological support and effort, better planning and efficiency in implementation thus pushing the banks to design various electronic money products.

\section{LITERATURE REVIEW}

From the era of barter economy, metal and coins to gold and silver, continuing to the modern monetary systems and checks, and ending with the latest developments in the global currency, such as the introduction of cryptocurrency like Bitcoin, have passed centuries. Each type of money plays a crucial role in transactional activities in some period of time. As human society and markets developed in particular, there was a need for more sophisticated instruments for the exchange of goods.

There are two reasons for the emergence of electronic money and digital currencies. The first, according to the Austrian School of Economic Analysis money is a "social institution" subject to the already initiated institutional change and is interpreted as a consequence of a spontaneous evolution that should overcome the shortcomings of the swap and the double coincidence of desires $[6,7]$. Today e-money is the last stage of this development and represents an additional degree of institutional change [8].

Their main role is to support online e-commerce, enable transactions, reduce their costs, or replace the payment of money and coins in retail. The second reason for the emergence of emoney is the Information Revolution, which is characterized by the integration of electronic information processing and telecommunication technologies, which reduces the geographical differences by means of which information can be transmitted to the whole world. The Information Revolution has changed the financial sector, making payment modes more secure and more efficient, giving an additional reason for the emergence of new monetary innovations [5].

Unlike the information revolution, the emergence of e-money is a new way of processing information for transferring purchasing power. Many financial innovations are not a new form of money, but a different way of using existing money in transactions [9]. Regardless of the consequences of the mentioned technological development, the nature of the money is still identical i.e money serves as a means of exchange, as an asset and as a value. The nature of the money will never change, so the money will remain only an intermediary in the exchange of goods and services. The e-money card is a different payment method that allows electronic transfer of the value from the card to the terminal or from the card in the wallet, both in real time and through networks [3]. It is considered that e-money is the most important achievement that transfers the predetermined monetary value so it can be used for more transactions of lesser value. The e-pocket consists of a microcomputer that contains information about the monetary 
value that can be used. It is a higher degree of technological development compared to magnetic tape cards. Also, the e-pouch is more secure, which can reduce deception because cards with a chip can be more difficult to abuse than magnetic tape cards.

\section{OVERVIEW OF THE IT REVOLUTION AND INNOVATIONS RELATED TO MONEY}

From the aspect of the development of the e - payment method, digital currency is not physically printed by the Central Bank, too. For now, digital currency is considered with its own rules of the game. In the literature, all those who support the use of Bitcoin underscore the characteristic as a currency that does not cause financial crises. Namely, the view is that as banks can print more money to cover their national debt, thus devaluing their currencies, Bitcoin does not function in such a way.

Electronic payment method exists from the 1960s, i.e from the development of Electronic Funds Transfer (EFT), which became more sophisticated and applicable in a growing number of countries [2]. EFT implies the application of computer and telecommunication technology in payment. This method was used by banks and other financial institutions to exchange and transfer a large amount of money on a national and international level. The basis for the operation of EFT is that the money moves through a network as a substitute for cash or checks to execute a transaction. In this way, the time for paying should be shortened and the transaction costs reduced. The use of EFT has significantly increased with the emergence and acceptance of ATMs, which allow money transfer at the point of sale (EFTPOS). EFT is considered as first degree in the electronization of transactions.

In the early 1980s, thanks to the development of network technology, the costs of telecommunications and data processing were reduced, and electronic payments became more useful with the appearance of credit and debit cards, which for several years (after their appearance) became the most popular electronic small transaction tool. Also, the development of encryption has played a major role in successful card payments. This innovation is considered as a second degree in the electronization of transactions.

The growth and acceptance of card payments had negative consequences for the traditional way of payment. Many countries have made a move from the use of paper instruments, such as cash and checks, to the use of electronic instruments. For the first time in many countries, the number of checks payments has been reduced. Namely, checks as a very popular payment instrument loose the market role, thereby reducing their use [4].

\section{E- PAYMENT AND TRANSACTION COSTS}

Payments in classical trade require at least one buyer and one seller, with both having to have accounts in banks that are connected through clearing houses. Payments with traditional instruments such as checks require intervention of a financial intermediary like bank. Payment with e-money is similar to the traditional scheme - there are two parties - one or two banks. However, the whole process becomes more efficient and easier. The transaction does not require any code and cannot exceed the previously defined amount. If the amount that is on the chip is fully spent, the card can be automatically refilled at the merchant, without charging any fees, thanks to the special POS mechanism [1]. 
Once the chip is full, the user does not need to require an ATM or an exact amount of cash. Additionally, the problem of stealing or losing money is reduced to a minimum. An e-money transaction does not require an intermediary at present because the money expressed in units (called bits) is electronically transferred from the buyer to the seller. The amount of money that has been paid is prepared at the seller's terminal, i.e. from time to time his account is transferred to the financial institution.

Payment with e-money reduces transaction costs, and time is shortened compared to other forms of payment. Humphrey and colleagues estimate that "the cost of using electronic money amounts to one third to half of the cost of paying paper money. When all transactions in one country would be carried out electronically, it would be possible to save more than $1 \%$ per year BDP.

\section{E- BANKING PLATFORM ANALYSIS USING MULTICRITERIA DECISION SOFTWARE: EXPERT CHOICE}

\subsection{EXPERT CHOICE ANALYSIS}

The Expert Choice program is based on the principles of multi-criteria decision-making using the method of analytical hierarchical processes (AHP). On the other hand, the AHP method in determining weight coefficients and deciding on the optimal alternative is based on the Saaty scale. In order to find the best software alternative for the development of the electronic banking platform, the first seven best software solutions were selected in the world. The current positioning of these software solutions in electronic banking does not mean that they are the best choice for a given banking organization, since each organization has its own specificities in the way it operates. It is important to note that using the Expert Choice program and the application of the AHP method, the model consistency index should be considered, which should not be greater than 0.1 in order to satisfy the validity of the model itself and the relationship of attributes and alternatives. In order to best optimize the ranking of these software solutions, certain attributive factors have been selected which in the best possible way represent the characteristics of the electronic banking platform in the author's opinion. They are grouped into three major parts:

- Systems factors for E- banking platform development:

- Scalability,

- Interoperability,

- Fast server response,

- User- friendliness,

- Networking,

- Big data analysis,

- Data aggregation,

- Security,

- Easy application navigation,

- Real time information transmission,

- Web- based platform,

- Providers,

- Expert chat availability. 
- Organizational factors for E- banking platform development:

- Multistakeholders perspective,

- Bank image,

- Resource allocation.

- Economic factors for E- banking platform development:

- Operational efficiency,

- Administration costs,

- Innovation diffusion,

- Financial information assistance.

The top seven world software alternatives for e- banking platform according to Capterra are:

- COBIS Microfinance Softwares,

- EBANQ,

- NovoDoba,

- Kapowai Online Banking,

- TEMENOS T24,

- Apex Banking Software,

- Secure Paymentz.

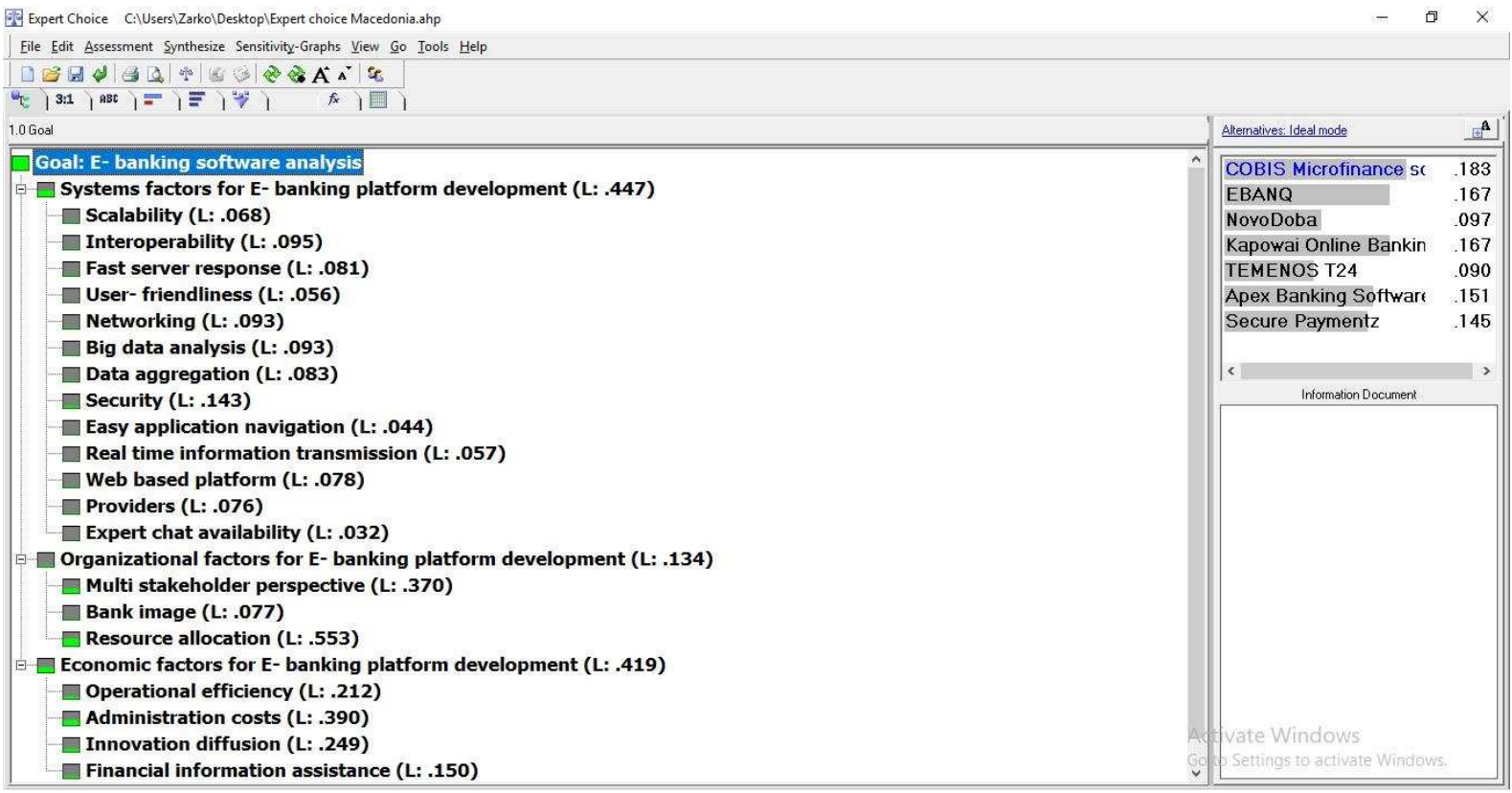

Based on the first picture, it can be concluded that the ranking of the best ranked alternatives based on the aforementioned criteria has changed in view of the specificity of the banking sector and business practices, but that COBIS Microfinance Softwares retained its original position. On the other hand, alternatives such as EBANQ (0.167), Kapowai Online (0.167) and Apex $(0.151)$ match each other and show favorable ranking in the overall score. The last alternative of which is the 0.09 rank is TEMENOS T24. 


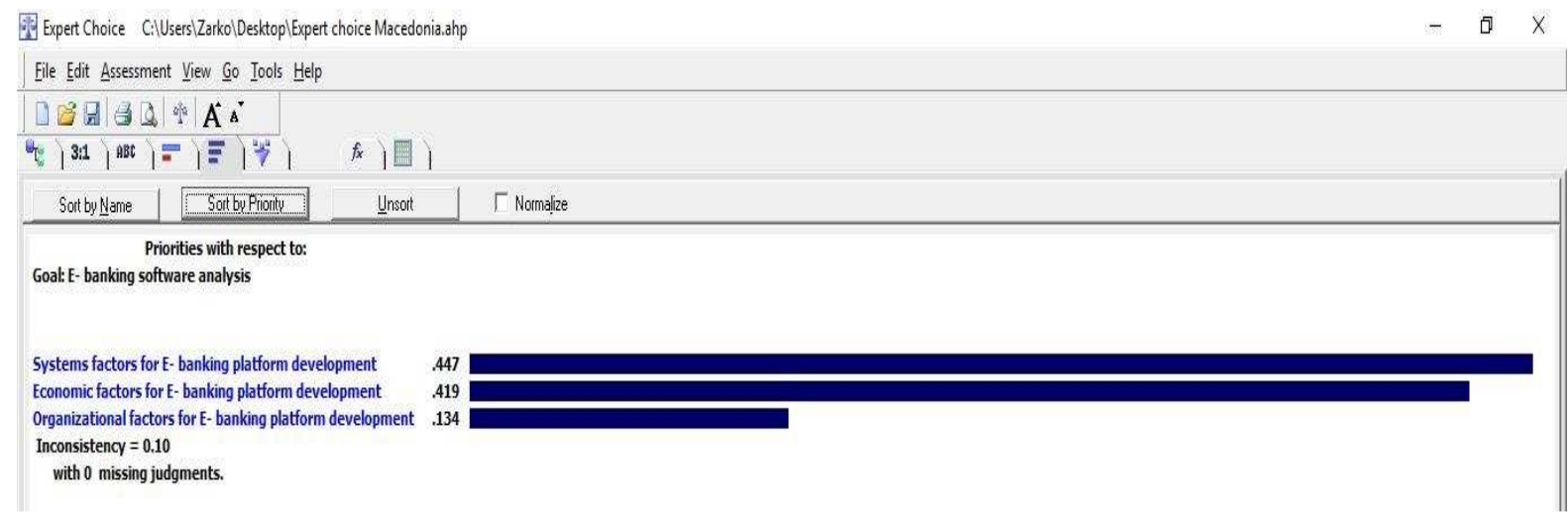

The most influential factors in choosing a software solution for electronic banking are Systems factors for E- banking platform development.

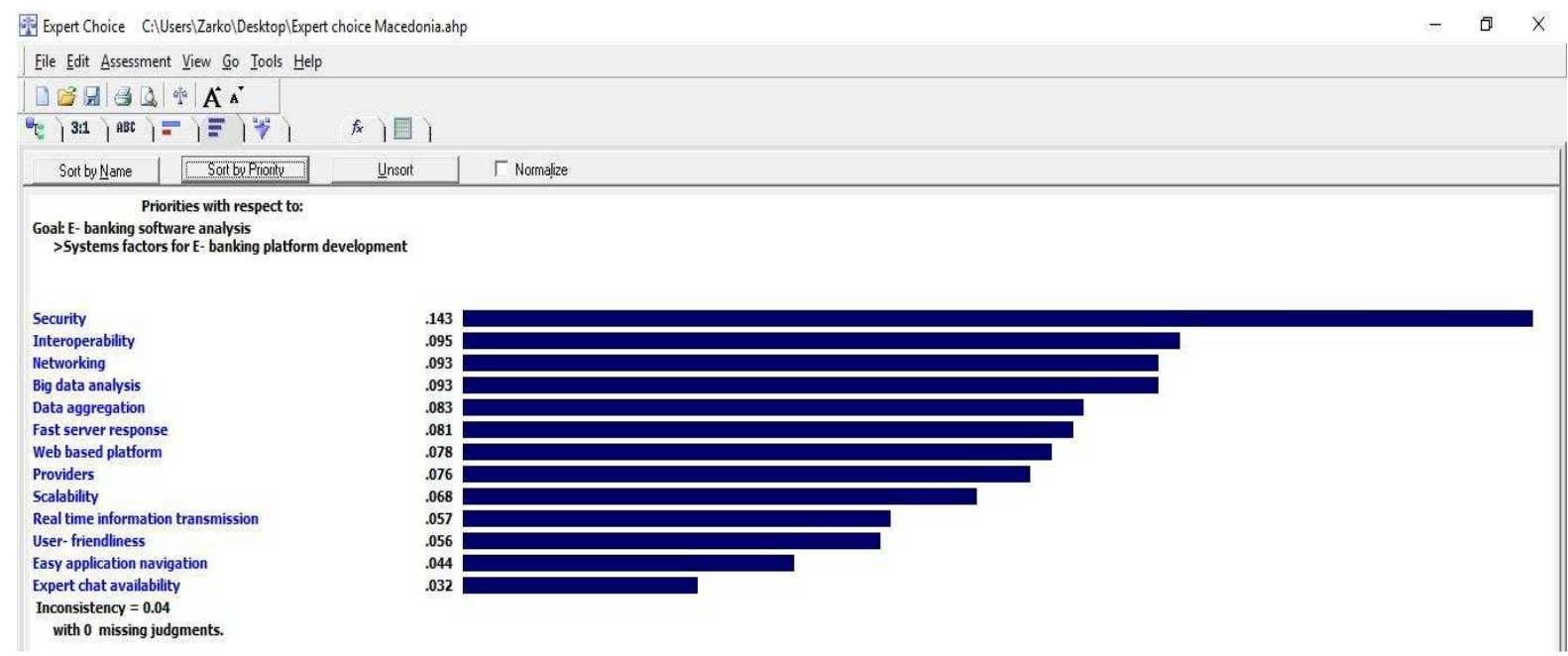

Also, the factor that is most distinguished within the mentioned group is of importance Security. Also this criteria is followed by Interoperability, Networking and Big data analysis.

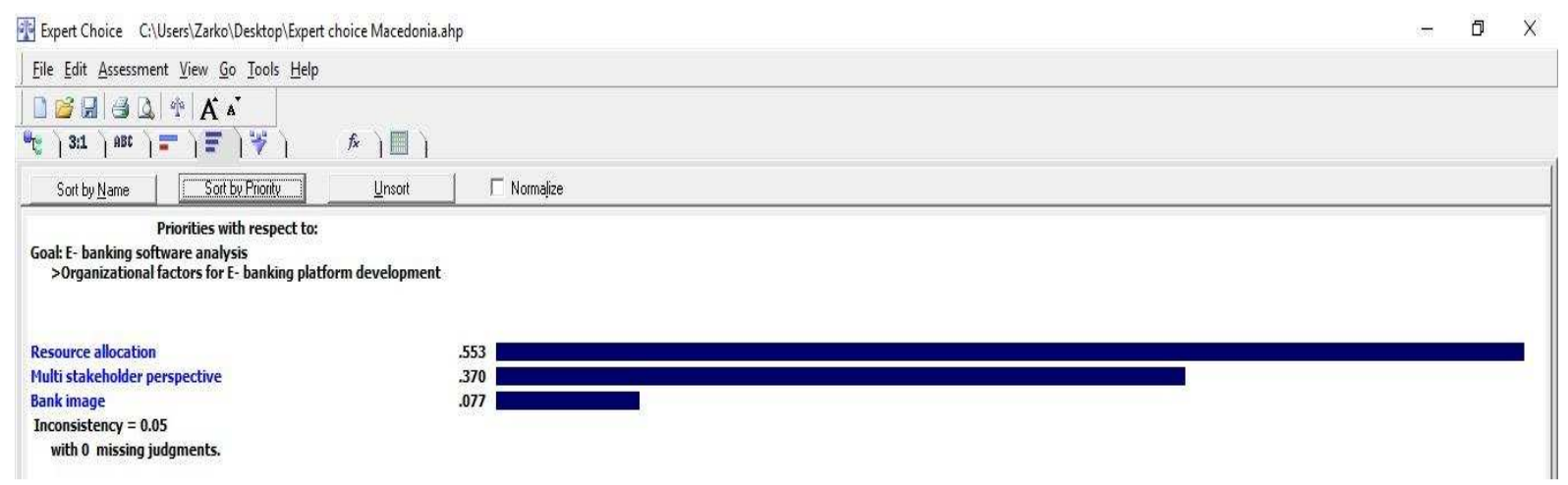

On the other side, the most ranked criteria from the second factor group is Resource allocation. 


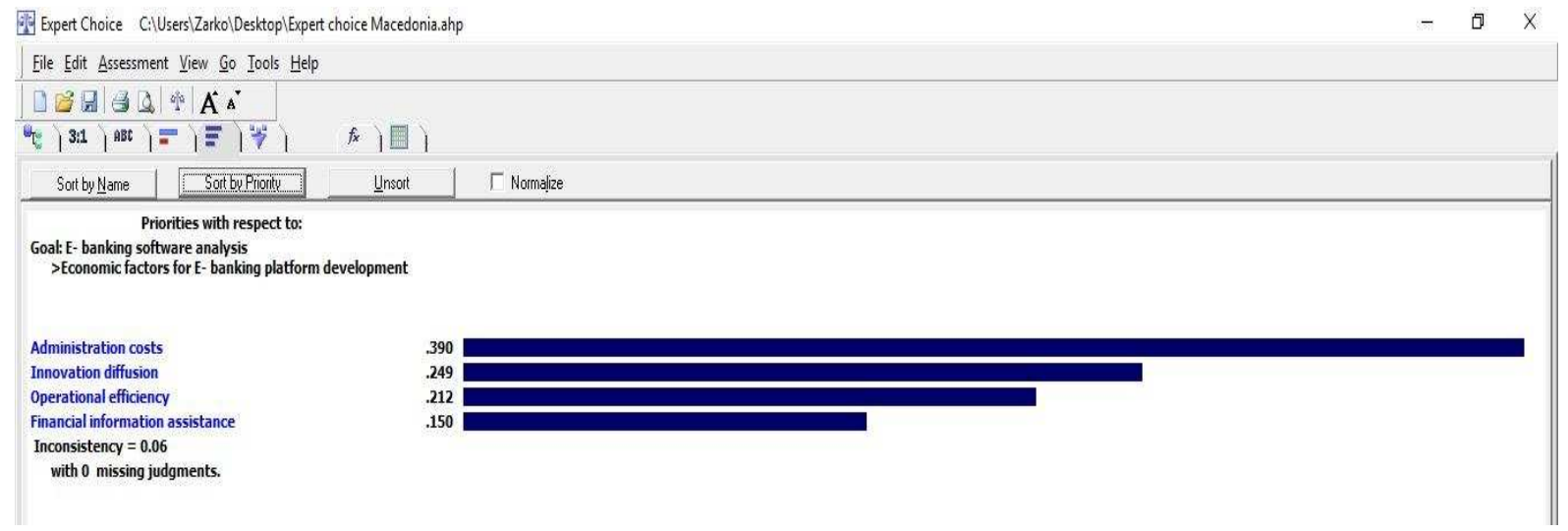

In the group of economic factors which influences on the e- banking software decision the most important criteria are Administrative costs.

Particular attention is paid to Performance Sensitivity Analysis, which shows the influence of particular criteria from the first group of factors on the ranking of alternatives in the final order. The influence of the weight of all criteria on the final ranking of the alternatives leads to the fact that the chart clearly reads the best alternative, as well as its advantage over competitors according to the chosen criteria.

The value of the criteria and the sensitivity of their movement in a given interval are shown by vertical rectangles, while the alternatives are represented by horizontal lines. The weight of the criterion is defined by the height of the rectangle, which is read on the left axis of Obj\%. On the other hand, the priority of the alternative according to a given criterion is formed in the cross section of their horizontal lines with a vertical line of criteria, which can be read on the right axis Alt\%. The values of the criteria determined by the height of vertical reagents are of a dynamic type, and by their shift, the values of the criteria themselves change, but also their influence on the alternatives themselves and their ranking.

For example, sensitivity analysis give us different ranking according to systems factors which have the biggest impact on the e- banking software solutions beside the other two factor groups. On the second plays now is Secure Paymentz and the factors with the biggest impact on its implementation from the first factors group are noticed on peaks of its chart: networking, security, real time information transmission and providers. 
File Options Window

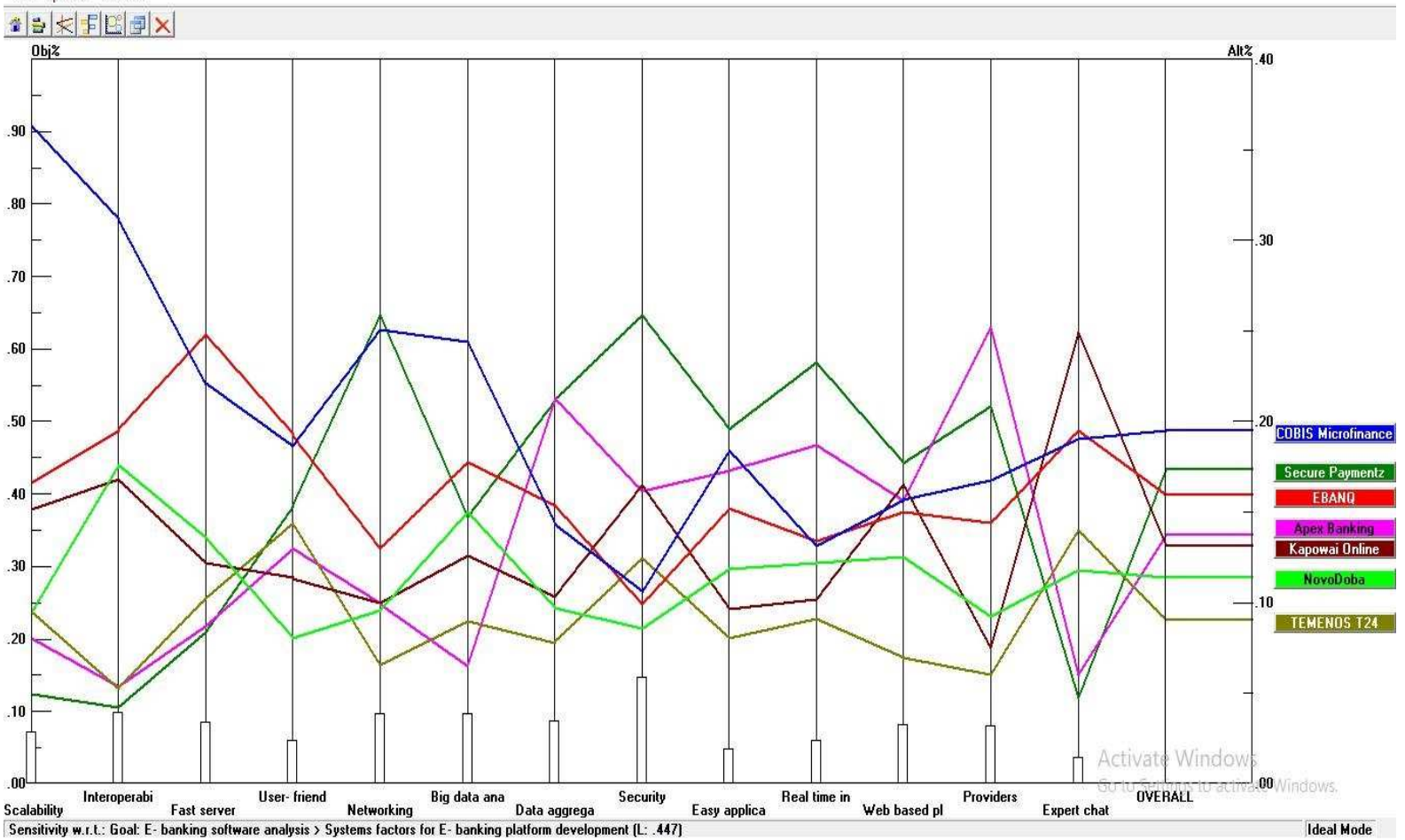

By applying dynamic analysis, one can see how dynamically changing the priorities of the alternatives in changing the weight of particular criteria. This view allows us to review the overall contribution of the weight of particular criteria in prioritizing alternatives. If we change the weight of one criterion, the other weights change proportionally to the initial weight of the criteria. On the left side are shown the percentage values of the impact of particular criteria on the priorities of the alternative. The expert chat availability criteria has the lowest contribution in e- banking software ranking and further implementation according to the first factors group.

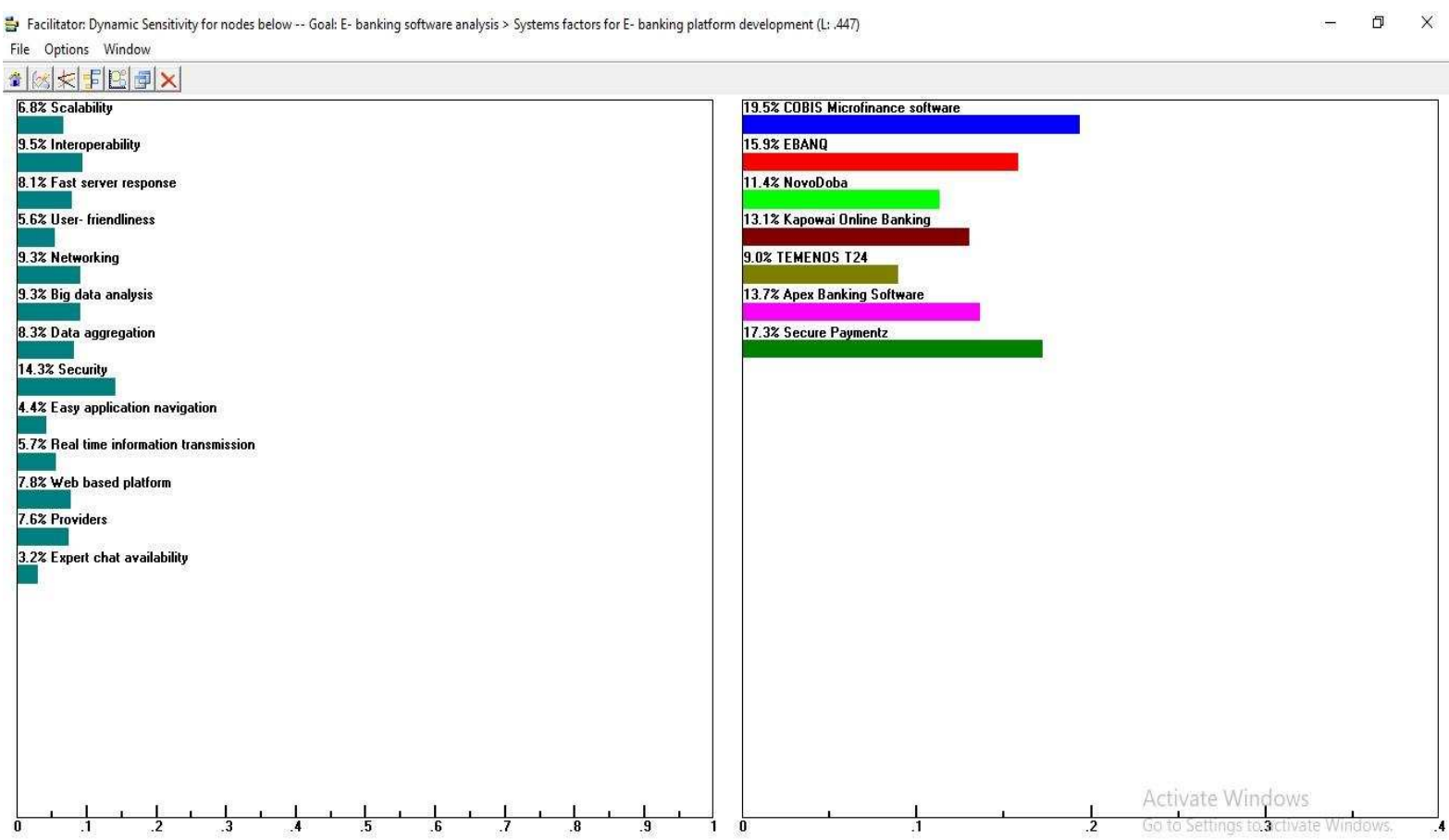




\section{CONCLUSION}

Advances in information and communications technology have enabled the appearance of new methods of electronic payment in the real world and the virtual world. The reason for the spread of these products has been their greater effectiveness compared with the traditional payment systems. However, statistics on payment systems indicate that electronic money development is still at an early stage of development and that cash continues to be the most important means of payment for retail transactions. Thus, contrary to some early expectations, cash has not been yet replaced by electronic money.

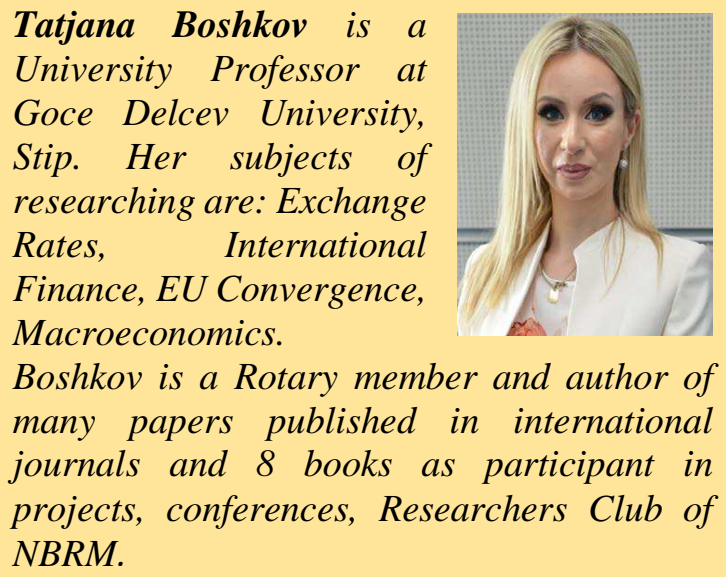

The most influential factors in choosing a software solution for electronic banking are Systems factors for E- banking platform development. Also, the factor that is most distinguished within the mentioned group is of importance Security. Also this criteria is followed by Interoperability, Networking and Big data analysis. On the other side, the most ranked criteria from the second factor group is Resource allocation.

In the group of economic factors which influences on the e- banking software decision the most important criteria are Administrative costs. Particular attention is paid to Performance Sensitivity Analysis, which shows the influence of particular criteria from the first group of factors on the ranking of alternatives in the final order. The influence of the weight of all criteria on the final ranking of the alternatives leads to the fact that the chart clearly reads the best alternative, as well as its advantage over competitors according to the chosen criteria.

For example, sensitivity analysis give us different ranking according to systems factors which have the biggest impact on the e- banking software solutions beside the other two factor groups. On the second plays now is Secure Payments and the factors with the biggest impact on its implementation from the first factors group are noticed on peaks of its chart: networking, security, real time information transmission and providers.

By applying dynamic analysis, one can see how dynamically changing the priorities of the alternatives in changing the weight of particular criteria. This view allows us to review the overall contribution of the weight of particular criteria in prioritizing alternatives. If we change the weight of one criterion, the other weights change proportionally to the initial weight of the criteria. The expert chat availability criteria has the lowest contribution in e- banking software ranking and further implementation according to the first factors group.

Governments could play a potentially significant role in changing the habit persistence problem and thus promoting the use of e-money. For instance, by encouraging the use of e-money in small transactions such as public parking meters and public transportation services, they could significantly increase the number of users of electronic forms of payment, helping to achieve the critical mass of users necessary to trigger network effects. 


\section{REFERENCES}

[1] Baddeley, M., 2004. 'Using E-Cash in the New Economy: An Economic Analysis of Micropayment Systems' [online]. Journal of electronic commerce, 5 (4), 239-253.

[2] Bounie, D. and Abel, F., 2006. "Les déterminants de la détention et de l'usage des instruments de paiement: éléments théoriques et empiriques". Revue d'Economie Financière, 174.

[3] Chakravorti, S. and Victor, L., 2006. "Payment instrument choice: The case of pre-paid cards". Economic Perspectives, 2Q, 29-44.

[4] European Central Bank, 2005. The Blue Book. Bucharest: European Central Bank.

[5] Goodhart, C. A. E. and Krueger, M., 2001. "The Impact of Technology on Cash Usage". The magazine of De La Rue, (4), 9-11.

[6] Hayek, F. von., 1976. Denationalisation of Money: An Analysis of the Theory and Practice of Concurrent Currencies. Londres: Institute of Economic Affairs.

[7] Menger, C., 1892. "On the origin of money". Economic Journal, 2 (83), 239-55.

[8] Schmitz, S. W., 2001. "The Institutional Character of Electronic Money Schemes: Redeemability and the Unit of Account" in M. Latzer and S. W. Schmitz, eds. Carl Menger and the Evolution of Payment Systems: From Barter to Electronic Money. Cheltenham, UK and Northampton, MA: Edward Elgar.

[9] White, L. H, 1996. "The Technology Revolution and Monetary Evolution" in J. A. Dorn, ed. The Future of Money in the Information Age. Washington, D.C.: CATO Institute 